University of South Florida

DIGITAL COMMONS

Digital Commons @ University of

@ UNIVERSITY OF SOUTH FLORIDA

South Florida

Educational and Psychological Studies Faculty

Publications

Educational and Psychological Studies

2016

\title{
Using Song Lyrics to Enhance Counselor Trainee Perceptions of their Reflective Listening Skills
}

\author{
Eric S. Davis \\ University of Nebraska Kearney, esdavis1@usf.edu \\ Jennifer Pereira \\ Arizona State University
}

Follow this and additional works at: https://digitalcommons.usf.edu/esf_facpub

\section{Scholar Commons Citation}

Davis, Eric S. and Pereira, Jennifer, "Using Song Lyrics to Enhance Counselor Trainee Perceptions of their Reflective Listening Skills" (2016). Educational and Psychological Studies Faculty Publications. 164.

https://digitalcommons.usf.edu/esf_facpub/164

This Article is brought to you for free and open access by the Educational and Psychological Studies at Digital Commons @ University of South Florida. It has been accepted for inclusion in Educational and Psychological Studies Faculty Publications by an authorized administrator of Digital Commons @ University of South Florida. For more information, please contact digitalcommons@usf.edu. 


\section{The Journal of Counselor Preparation and Supervision}

Volume 8 | Number 1

Article 2

September 2015

\section{Using Song Lyrics to Enhance Counselor Trainee Perceptions of their Reflective Listening Skills}

Eric Davis

University of Nebraska Kearney, davises@unk.edu

Jennifer Pereira

Arizona State University, jkpereia@asu.edu

Follow this and additional works at: http://repository.wcsu.edu/jcps

Part of the Higher Education Commons, and the Other Social and Behavioral Sciences Commons

\section{Recommended Citation}

Davis, E., \& Pereira, J. (2016). Using Song Lyrics to Enhance Counselor Trainee Perceptions of their Reflective Listening Skills. The Journal of Counselor Preparation and Supervision, 8(1). http://dx.doi.org/10.7729/81.1066

This Article is brought to you for free and open access by WestCollections: digitalcommons@wcsu. It has been accepted for inclusion in The Journal of Counselor Preparation and Supervision by an authorized administrator of WestCollections: digitalcommons@wcsu. For more information, please contact kenausisv@wcsu.edu. 


\title{
Using Song Lyrics to Enhance Counselor Trainee Perceptions of their Reflective Listening Skills
}

\begin{abstract}
This qualitative study explored counseling student perceptions of the use of song lyrics to practice reflective listening skills. Student perceptions included reactions to a creative technique, increased confidence in reflective skills, applicability of skills, and potential issues with this activity. Results, implications for counselor education, and future research are explored.
\end{abstract}

\section{Author's Notes}

Correspondence concerning this article should be sent to Eric Davis at davises@unk.edu

\section{Keywords}

Song lyrics, Music, Facilitative skills, Experiential learning 
The teaching and learning of counseling skills is both time and labor intensive (Ray, Jayne, \& Miller, 2014). Counseling trainees must understand, learn, and apply numerous skills (e.g., paraphrasing, summarizing, confrontation, reflective responding) throughout their training work. These new skills then become the foundation for further learning of counseling theories, specific techniques, diagnosis, and treatment. It is imperative, therefore, that this initial acquisition of skills be successful, leaving counselor educators to present the material in innovative and meaningful ways (Furr \& Carroll, 2003; Iarussi, Tyler, Littlebear, \& Hinkie, 2013; Paladino, Barrio-Minton, \& Kern, 2011). Research regarding these creative ways includes the use of movies and television as skill training tools (Koch \& Dollarhide, 2000) and, to a lesser extent, music (Taub \& Forney, 2004). Taub \& Forney (2004) recommend the use of music from the standpoint of setting the atmosphere for learning or using particular lyrics to help students remember the stages of counseling.

The current study was designed to investigate the use of song lyrics and music as a potential tool to enhance student learning of reflective listening skills. In particular, this tool is being explored as a way to aid students in understanding the client's tone and affect, story and meaning, and further developing the in-depth process of reflective listening. The rationale for this study was drawn from the literature on experiential instructional modalities used to enhance basic counseling skills with counselors in training. The authors propose the use of music and song lyrics as a supplementary classroom tool based on the results of a qualitative study with students currently enrolled in a master's level counselor education program. 


\section{Pedagogy of Counseling Skills}

Within the field of counselor education, literature and study on the pedagogy of basic counseling skills is paramount to understanding how we can best support the learning of counselors-in-training. Tang, Kathleen, Lasure-Bryant, \& Norman (2004) assert that a primary mission of most graduate counselor education programs is training their students to be successful practitioners. In particular, facilitative listening skills have been found to have the highest prediction of outcome and this therapist characteristic "represents a quality of the therapist that impacts clinical outcomes" (Anderson, Ogles, Patterson, Lambert, \& Vermeersch, 2009, p. 764). The discussions in the literature focused on pedagogy for counselors-in-training suggest that student counselor competency is enhanced in environments wherein counselor trainees are guided in developing critical thinking and therapeutic skills that are related to real-world counseling activities (Buser, 2008; Furr \& Carroll, 2003; Iarussi et al., 2014; Tang, et. al., 2004). The ability of counselors to use appropriate therapeutic skills in real-life counseling settings is strongly influenced by their identification of specific skills and their ability to be confident in the use of those skills, thereby directly affecting the quality of counseling services provided (Ivey, Ivey, \& Zalaquett, 2010; Ray et al., 2014). Therefore, students may be best served when the pedagogy and curricula of counselor education programs seek to enhance skill acquisition, understanding, and application in novel and engaging ways that can appeal to a variety of learners.

There are numerous counselor-training models that provide focused attention to both reflective and action-oriented skill building, allowing counseling students to attain skill development in essential counseling skills and client awareness (Carkhuff, 1969; Ivey, Ivey \& Zalaquett, 2010; McCauliffe, 2011). Empathy and active listening skills are crucial components 
of the counseling relationship (Carhuff, 2000; Ivey et. al., 2010; Ray et al., 2014; Rogers, 1986). In particular, clients who have worked with counselors who used reflective listening skills reported feelings of empowerment, satisfaction, and ability to make their own decisions, as well as feelings of a stronger therapeutic alliance with the counselor (Bogner, Horrocks, Lanni Manley, \& Denig, 2012; Marmarosh \& Kivlighan, 2012; Thompson \& Hill, 1991). The field recognizes Roger's (1986) core conditions of empathy, unconditional positive regard, congruence, and the skill of empathic responding to be important foundational constructs for counselors-in-training to master (Gladding, 2006; Pereira \& Smith, 2013). While these constructs are paramount, Nalavany, Ryan, Gomory, and Lacasse (2005) found that therapists rated facilitative listening skills as the most difficult to master during training. Furr and Carroll (2003) and Paladino et al. (2011) argue that counseling skill development begins in the earliest courses where students begin to identify their individual counseling style and manner of relating to others. These initial courses, such as an introductory counseling skills course, are often a student's first foray into using focused and purposeful communication skills in conversation with others rather than their typical day-to-day manner of building relationships and conversing. This new knowledge can often be difficult for students to incorporate into their current schema, calling for innovative methods in teaching.

\section{Experiential Modalities in Teaching Counseling Skills}

The field of counselor education has been growing rapidly with regard to the inclusion of experiential modalities in the classroom such as role play, case studies, play based activities, art activities, gaming, and use of media (Smith, 2009; Swank, 2012; Taub \& Forney, 2004; Villalba \& Redmond, 2008; Ziff \& Beamish, 2004). Additionally, there is writing on the effectiveness of using popular media to inform teaching as it relates to counseling skills (Stintchfield, 2008; Taub 
\& Forney, 2004; Villalba \& Redmond, 2008). The skills focused on basic counseling skills both in counselor education and related fields such as social work and student affairs and consist of: attending, reflective listening skills, paraphrasing, summarizing, therapeutic questioning, goal setting and action planning (Ivey et al., 2010; Ray et al., 2014; Taub \& Forney, 2004). Currently, there are a number of training videotapes available that explore and display the counseling skills being taught to students in the classroom. These videos can be helpful supplements to the curriculum, as they provide additional examples of the specific components of a counseling interaction that bring the process to life for students, preparing them for roleplays and practice.

Researchers (Taub \& Forney, 2004; Villalba \& Redmond, 2008) demonstrated that popular media has many examples of feature films and television shows (e.g. Good Will Hunting, Ordinary People, Quill, In Treatment, One Flew Over the Cuckoos Nest) that can be used to illustrate the process from the perspective of the counselor and client to aid students in becoming comfortable with, understand, and work with emotions. Films have also been used to support the understanding of group counseling, counseling theories (Koch \& Dollarhide, 2000), client issues, diagnosis, and mental illness. Similar to movies, popular music can be utilized to support a number of aspects of learning taking place in the classroom. The current use of music centers largely around setting the tone for the class, supporting the retention of information, forming connections between information and life experiences, understanding the stages of the therapeutic process, and assisting students with the self-reflection process (Baker \& Krout, 2011; Koch \& Dollarhide, 2000; Taub \& Forney, 2004; Villalba \& Redmond, 2008). Using music in this way helps to illustrate certain constructs being taught in the curriculum and can be used as a catalyst for discussion and role play (Taub \& Forney, 2004). Often in counseling coursework 
such as multicultural competencies, skills, trauma, and counseling children and adolescents, students need some help adjusting to the content and tone of what they will be discussing and learning (Villalba \& Redmond, 2008). Instructors can play music that tells a story about cultural issues (i.e. Rap), exemplifies trauma scenarios (i.e.: songs detailing abuse or domestic violence), and playing common children's songs can be helpful to remind students to be aware of the developmental differences they will encounter with young clients. Additionally, music can assist with helping students understand steps or constructs in theoretical models and the application of counseling skills (Taub \& Forney, 2004). Within the complementary field of music therapy, music and lyrics are often used in the classroom to support deeper self-reflection while students are engaged in moving from theory to practice and applying skills to practice (Baker \& Krout, 2011). This reflection is a crucial factor as it supports student integration of theory, research from the field, and skills based knowledge. The literature on music therapy also provides rich examples of how engaging in creative arts activities can enhance student development of clinical skills and higher levels of professional decision making (Baker \& Krout, 2011; Shulman-Fagen, 2001).

A skill paramount to therapeutic work with clients is reflective listening (Carhuff, 2000; Iarussi et al., 2014; Rogers, 1986). While there is limited research regarding the use of music as a method for introducing, understanding, and mastering the specific skill of reflective listening, there is literature in the music therapy field illustrating the use of music and lyrics for understanding emotional expression (Craig, 2009). The musical score of a song has the potential to assist students in feeling the emotion the artist is trying to convey, similar to when a counselor listens for the latent or unexpressed emotion felt by clients in a session. The use of lyrics may also assist students in understanding the underlying meaning of the story the artist is telling, the 
subtext, and the subplots, which is akin to listening for the underlying meaning in a client's retelling of their story. The current study aimed to mesh the power of music and lyrics to help counselors in training better hear the emotion, understand the deeper meaning of the story, and respond appropriately using the information gathered by exploring the following questions: What are counseling students' perceptions of the viability of using song lyrics as a technique in identifying emotional content through a classroom based learning activity? What are counseling students' perceptions of using song lyrics in enhancing their levels of confidence for identifying and understanding emotional content? What are counseling students' perceptions about using song lyrics in increasing counseling based reflective listening responses to emotional content?

\section{Method}

In this study, researchers used a constant comparative method and a thematic analysis to examine reflective feedback written by graduate students participating in an introductory counseling skills course. Thematic analysis is an inductive data driven approach to coding data into meaningful concepts or themes (Boyatzis, 1998). This approach was selected because it relies on the data to drive the formation of ideas and is consistent with a constructivist paradigm. To code the data more systematically, a constant comparative method was used that includes open, axial, and selective coding (Patten, 2007; Potrato, 2010). A constant comparative process

involves selecting a data set, developing data-driven codes, and applying the themes to the full data set to determine similarities and differences. The resulting codes were then analyzed for common themes related to the graduate students' experience. 


\section{Participants}

A purposeful sample of 16 counselors-in-training from both the mental health counseling (11 students) and marriage and family therapy (5 students) concentrations (14 females; 2 males) served as participants. Participants were all enrolled in an introductory counseling skills course in the fall and spring offerings of the course during one academic year and taken at the beginning of the academic program at a southeastern university. Their ages ranged from 23-47 years of age with a mean age of 31 and of the 16 participants, five were African American, six were Caucasian, and five were Latino students. The small purposeful sample was not intended for generalization to a larger population. Rather, the intent of this study was to understand the experiences of a specific group of graduate students as they were immersed in a classroom-based learning activity. Participation in the study was not part of the overall grade in the introductory skills course and the student's participation in this study was completely voluntary. Thus, there was no actual or implied penalty in the students' performance in the introductory skills course for choosing not to participate in the study. Participants were assigned letters (A-J) to maintain confidentiality. The university's Institutional Review Board approved all aspects of the study and the researchers adhered to the ACA Code of Ethics regarding treatment of participants (American Counseling Association, 2014).

\section{Procedures}

The introductory counseling skills class met on site at the university and addressed a variety of basic counseling skills (i.e. reflective statements, summarizing, therapeutic questioning, paraphrasing, etc.). Because one of the most important underlying components of counseling is the ability to listen to a client's story and accurately understand the content, affect, and tone to allow for potential emotional insight to the situation, the researchers focused on 
reflective listening skills for this study (Ivey et al., 2010). Graduate students were expected to demonstrate their ability to listen to the song for aspects of tone, content, and affect to gain better awareness of the story and provide appropriate reflections that could potentially allow for insight into the client's issues.

The students were introduced to the basic components of reflective listening as part of the regular course curriculum immediately prior to engaging in the study. The course curriculum students engaged in for purposes of this study remained the same as what would be taught during the typical four-hour course meeting for that week utilizing the teaching, demonstration, and practice of reflective listening skills utilizing traditional methods (e.g. lecture, discussion, role play). The researchers wanted to assess the viability of this tool as a way to help students build mastery with the skills. Three assessment tools were utilized in the research study. These tools included a case study example, three songs with lyrics, and a reflective questionnaire for data collection. The purpose of each of these tools will be explained in the following paragraphs.

A case study was created from the lyrics of the first song "Pumped up Kicks" used in the study (See Appendix A, "Pumped Up Kicks" by Foster the People, 2010) to allow students to engage with a familiar teaching tool, and compare that with a new tool being explored. Case studies are commonly used in the classroom as a medium for presenting and addressing the client's story (Harrawood, Mariska, \& Hill, 2013; Keri, 2002). Students were asked to assess the case study as the first component of the research for client tone, affect, and content and to follow this with reflective listening statements. For the second component, which was musical, three songs were selected based on a variety of factors: Pumped Up Kicks (Foster, 2010) chosen for its content regarding a teen boy dealing with potential familial abuse and aggressive behavior tendencies toward schoolmates; Still (Grey, Ruzumna, Esses, \& Blue, 2000) chosen for its 
treatment of domestic violence and drug abuse; All These Years (McAnally, 1992) chosen to illustrate the marriage and family counseling component of a couple in crisis related to infidelity. They provided diverse and emotionally driven stories that had potential for demonstration of the selected counseling skill of reflective listening. The songs also provided a mix of music, lyrics, and situations that could demonstrate the potential emotional aspects that clients may demonstrate in a session that either corroborate or mask the underlying emotion of the story. For example, the song could be utilizing upbeat music while the lyrics portray a lonely or aggressive story similar to a client who appears cheerful while describing a traumatic life event. This variety of song components provided a potentially more realistic experience for the students to listen to and for differences and similarities of common aspects of communication such as tone, content, and emotion seen in typical counseling sessions. Finally, the songs utilized crossed a range of genres thus allowing for exploration of culturally diverse music and situations similar to the array of clients and issues that students may work with during their future practices.

Following the case study activity, the remainder of the study was conducted in three stages for each of the three songs. The participants listened to the first song and wrote their notes concerning the tone, content, and affect noted in the song on a sheet with columns for tone, content, and affect. Then the participants received the lyrics to the song and listened again adding to their notes. Then they listened to the song again that was paused at intervals to record their reflections to address the emotional content detected in the song lyrics. The participants and researchers then processed the notes and reflective statements. This process was repeated for the next two songs. 


\section{Data Collection}

Following the completion of the activity, the counseling students responded in writing to four open-ended reflection questions regarding their perceptions of the experience. The openended questionnaires were designed to help the researchers understand the context in which the participant perceived the experience. For example, in order to better understand how counselorsin-training constructed their song lyric learning experiences, participants were invited to reflect on their perceptions of using the experience to identify emotional content, enhancing their confidence in identifying emotional content, and increasing counseling based responses to emotional content. Items similar to the reflection questions included in this study have been proposed as appropriate ways to assist participants in deeply processing their experiences in the study (Patten, 2007). Sixteen reflection questionnaires were collected for data analysis. Each questionnaire included the following questions:

a. What is your perception of the viability of this technique in identifying emotional content in song lyrics?

b. What is your perception of the training tool in enhancing your level of confidence for identifying emotional content?

c. What are your perceptions about this training tool in increasing counseling based responses to emotional content?

d. Do you have any additional comments regarding this experience? 


\section{Data Analysis}

The reflective questionnaires written by the counselors-in-training were collected and examined using a thematic analysis. Categories derived from a thematic analysis are intended to provide an in-depth picture of the collective experience of the participants and to describe the meaning of their own reflections rather than to provide an over-arching explanation of the process (Aronson, 1994; Braun \& Clarke, 2006; Grbich, 2007). In this study, constant comparative methods were used to give structure to the coding process.

In qualitative research, researchers completely immerse themselves in the data by constantly reviewing the materials as themes emerge (Potrata, 2010). For this early coding process, the two researchers first reviewed and coded the questionnaires independently, using an open coding procedure to examine the questionnaires for distinct segments and sort them into categories that emerged (Grbich, 2007; LaRossa, 2005). Subsequently, the researchers met to discuss axial coding of the data and organized six categories, and several sub-categories that described common themes that emerged from the open coding. Finally, the researchers identified four over-arching categories that related most to the research questions. The researchers met multiple times to compare coding results, examine the themes against the original data, negotiate their applicability, and revise the categories when necessary.

Member checking was used in this study as a measure of the accuracy and trustworthiness of the data analysis (Patten, 2007). Eight participants contacted by email responded and were provided findings of the data analysis to review and offer any additional feedback, information, or questions. They used the following questions to guide this review: 1) Generally, do these findings fit with your song lyrics experience? 2) Is there anything in the 
results that does not seem accurate to you? 3) Is there anything that seems particularly accurate to you? The students all indicated that the data analysis results fit with their experiences.

\section{Results}

Results of the data analysis produced four overarching categories addressing the participants' perceptions of the song lyric training tool experience. Each category is discussed below, including themes and quotes that illustrate the students' experiences in this basic active listening skills training opportunity. Note that no students are identified by name to ensure confidentiality is maintained.

\section{Creative and Useful Method}

Participants noted the creative, fun, and useful aspects of this novel training tool utilizing music and song lyrics to teach basic active listening skills related to emotional content. This finding is significant considering the fact that proper identification of emotional content can aid in a more authentic process of counseling (Ray et al., 2014). Students appreciated the idea of utilizing the popular media form of music to learn about active listening skills due to their personal connections to songs. As participant E stated, "For me, it is much easier to connect to a song than a written or verbal story" and "music connects the emotions much more than a written or verbal word and it can be used in many different ways." A majority of the participants also noted the expansive potential of this new teaching tool to enhance the existing methods used in training counseling students in basic attending skills. For example, participant D shared, "I think listening to emotional content in song lyrics is a creative and useful tool to broaden the spectrum of tools used to understand clients and their stories." These statements reflect the desire of the participants to utilize creative methods for learning these basic counseling skills, as well as the potential for applying them for their future work with clients. 
Students also discussed the prospective applicability of this teaching tool beyond the parameters of this brief study. For example, participant K remarked, "I think this would be effective. I appreciate the teaching piece that I know could be expanded in a full class." Participant E made the comment that she would like to "do more with music both in school and in practice." The participants also noted the possible utilization of the teaching tool outside of the traditional classroom setting. Participant M noted, "it is something I could use daily when not in class." Participants A and L shared that they plan to "use this at home to improve my ability to actively listen and reflect" and to "constantly be practicing my skill sets." Further, participants noted the applicability of this tool as a safe means of practicing these skills before meeting with clients. Participant N said "I feel more confidence...this is an exercise I can practice at home instead of having to wait for a client to practice on" and "without hesitation or fear of being wrong" thus addressing the common theme of anxiety often seen in counseling students during their training of basic counseling skills. This was also documented in one participant noting, "It shows future therapists different ways to identify important cues used to understand and later reflect the clients' problem/story." These statements suggest that the participants in this specific study desire a creative teaching activity to enhance the learning environment, as well as a portable means of practicing active listening skills beyond the classroom setting which has the potential for increased engagement and significant learning (Buser, 2008; Koch \& Dollarhide, 2000).

\section{Enhancement of Confidence in Active Listening and Reflecting Skills}

Participants described the development of active listening and reflecting skills that many instructors would consider essential to quality professional counseling abilities. In particular, a majority of the students identified the positive experiences they had during the implementation 
of this training tool and the increase in their level of confidence in identifying emotional content, which is paramount in active listening and reflection (Anderson et al., 2009; Gladding, 2006; Pereira \& Smith, 2013). Students commented on aspects of their increased confidence including the identification of feelings, enhanced ability to note emotions beyond the lyrics of the songs, and ability to develop appropriate reflective responses.

Participant $\mathrm{C}$ confirmed the ability to identify feelings by stating, "My confidence level increased because I now feel like I know what I should be looking for, how to identify cues, and how to interpret them and utilize them." Participant J noted, "this approach to learning made the process much easier to comprehend and better able to identify emotional issues." Participants identified the usefulness of this training tool in addressing emotional content than traditional training methods. For example, participant E said, "I was able to connect and identify much better to the emotional content using the music and song lyrics than I was with a case study" while participant $\mathrm{O}$ stated this tool provided “tangible examples of how to bring the story's meaning out of the emotions." Participant D added, "My responses are now going to be more geared towards emotional content because that is where the important information hides." One explanation for this is how creative teaching tools like music and song lyrics add an emotional depth that may not be present in a role-play or case study (Taub \& Forney, 2004).

Meeting the need for more realistic and effective learning strategies to address emotional content in effective counselor training was a common theme. The participants documented the importance of addressing tone and content by noting increased confidence in the ability to identify emotional content beyond simply using the lyrics of the song. As participant A stated, "Being able to identify the emotional content allows for further opportunities to respond to the client, to feeling the emotion with music itself." The same participant also stated "the tone and 
affect allowed me to open my mind further in order to not become as biased by the lyrics along." The ability to go beyond the lyrics for insight and information was demonstrated by participant G who stated, "This tool was helpful in learning how to look for emotional content in dealing with clients. Otherwise, I may have gotten caught up in just the lyrics." Participant O commented, "Once you get beyond understanding that you are actually looking for each category (i.e. tone, content, affect), the reflective piece becomes much easier to develop."

Students also discussed the need this teaching tool addressed in utilizing their understanding of the emotional content to make appropriate reflective responses. For example, participant $\mathrm{K}$ made the comment that "I found this to be an effective tool in identifying pieces we will use in summaries and while we put together reflective pieces." Participant M also stated, "I feel this could be a very valuable tool for increasing counseling based responses to emotional content." It was also noted that this tool may enhance the learning experience by allowing the "emotion and story stand out" and it "almost leads you to various counseling based responses." These statements suggest that participants noticed an enhanced ability to identify emotional content as well as developing potential reflective responses with this teaching tool. This applicability of the active listening skills was another area that surfaced in the data analysis as a separate category.

\section{Applicability of Active Listening and Reflective Skills}

The ability of the participants to move beyond self-reported improved confidence in identifying emotional content to the application of the skills for conceptualization and reflective responses is paramount, as a primary goal of counseling skills training is to learn how to utilize the skills appropriately (Lee \& Prior, 2013). For example, one participant E documented, "I really liked writing out the tone, content, affect...it helped me with my reflective statements." 
Participant B also noted the experience showed that "emotions are a strong trigger" and the importance of listening for the "underlying message" in order to "get the whole picture and help them [clients] that much more."

Another important application of this training tool noted involved identifying potential incongruence between the content and emotion of a person's story. This was conveyed in participant I's statement that the training tool could be "helpful in preparing [counselors] for difficult sessions in which tone and affect don't match the story." Participant H exemplified this by saying, "I feel that this is something that is useful in counseling because you never know what we are going to get." While this training tool may have potential to address such difficulties for counselors-in-training, a series of themes related to potential issues with the tool also were observed.

\section{Potential Difficulties with the Training Tool}

As with any approach to learning, there are potential issues concerning the understanding and application of the techniques being taught (Iarussi et al., 2013). Participants noted a variety of factors that could interfere with this method for teaching active listening skills to counselors in training. These factors included clarity of the music and lyrics, familiarity or lack of familiarity/interest in music, and clarity of the instruction and concept.

Utilizing techniques such a music and song lyrics can potentially provide a more realistic picture of a client and verbal interactions these students may encounter (Koch \& Dollarhide, 2000; Taub \& Forney, 2004). For example, clients may present with a speech impediment, rapid speech, or low volume that could be difficult to understand, especially for students who may have a hearing problem. Some of the songs selected presented these examples and provided an area of difficulty for the participants. As participant A stated, "It was somewhat difficult to hear 
the lyrics." Another participant (C) noted that "it is important to combine the song lyrics with the music for clarity" and participant P stated a need for a "visual piece" to make the experience more effective. The tool does also provide a safe space to practice dealing with speech and hearing issues rather than working directly with a client or peer. Similarly, familiarity with a certain client issue or counseling area could influence interactions.

Some of the participants documented their apprehension for this approach as it related to familiarity to the medium of music and certain songs. For example, participant F observed, "I do not know how effective it would be for a person who does not relate to music." The same participant also noted that it "may make a difference if person/class already knows the song." Participant E also expressed concern that "not all people are into music" and therefore may not be as engaged in this learning tool.

The need for continued practice to fully gain a solid foundation for this new teaching tool was another area that surfaced. Participant $\mathrm{C}$ documented this by stating, "I need more practice to better understand the total concept." Participant J added that "without more practice" elaborating on the potential for increasing counseling based responses was not possible. These results are not unexpected considering the need for more training with a new teaching approach (Paladino et al., 2011; Ray et al., 2014). There was also evidence of potential for this approach in enhancing confidence in identifying emotional content. As participant A said, "I believe that this is a tool that has enhanced my confidence and could continue to enhance my confidence with more practice."

Additionally, there is a potential issue with student's personal issues being brought to the surface or highlighted by specific lyrical content. Students may react emotionally to the lyrics being used due to their own life history and experiences causing them distress and the instructor 
may need to process the content with the class as a whole or privately with specific individuals. This processing can also be an opportunity to help students to understand the transference and countertransference that can take place during a session.

\section{Discussion}

The teaching, development, and application of active listening skills and reflective statements can be a daunting task for both counselors-in-training and counselor educators (Ivey, Ivey, \& Zalaquett, 2010). As demonstrated by participant reports, through the use of a novel and creative tool, the process for learning these skills can be enhanced. The use of music and song lyrics for teaching active listening skills, according to participants, allowed for deeper understanding and connection to the emotional content of the practice experience. Further, we identified a majority of the students' eagerness to utilize this approach in class, but also for personal practice. This willingness to practice these skills beyond the traditional classroom setting identifies the need expressed by counselors-in-training and the profession to learn and hone the counseling skills needed for proper connection to client emotional content for depth, understanding, and progress in counseling (Anderson, et al., 2009; Iarussi et al., 2013; Ivey et al., 2007).

Creative methods for counselor training have been shown to be effective in the development of a variety of skills such as empathy and reflective listening (Iarussi et al., 2013; Villalba \& Redmond, 2008). For a majority of the participants, using music and lyrics provided an experience that assisted in the development of several counseling skills. The students identified how the experience helped them understand emotional content in a more authentic and substantive manner and better conceptualize the client story without focusing solely on the content of the words or lyrics. The tone and effect added by the music allowed participants to 
focus beyond just the words to the underlying emotions expressed by the singer. This conceptualization provided participants with a better ability to express reflective statements that relate to the emotional content in a more genuine and consequential manner. This is an important aspect of the counseling relationship (Gladding, 2006; Pereira \& Smith, 2013; Ray et al., 2014; Rogers, 1989).

Apart from the recognition of this teaching tool as a creative means for enhancing and applying active listening and reflective statements, an important aspect was the increased confidence noted by the participants in developing these skills. The need for successful learning and application of counseling skills is critical for counselors-in-training (Anderson et al., 2009). The participants' increased confidence led to a greater understanding of paying attention to all aspects of clients' stories. This can help participants gain insight into the depth of the emotions present and utilize reflective listening to connect with clients.

\section{Limitations}

Because the goal of the qualitative research methodology employed in this study was to provide an in-depth examination of the participants' personal experiences, generalizability may be more limited when applied to similar populations. Due to the universality of teaching reflective listening skills and the growth of creative teaching modalities in the field, there is potential for this technique as a viable tool for teaching these skills. Additionally, the outcomes

of this study may be limited because the data was collected solely from a subset of graduate students enrolled in a course at a small university. Social desirability bias may have been present due to the lack of additional data sources (e.g. interviews, visual data, observations, etc.) and the students' awareness that the researchers were faculty members of the university and would review the questionnaires and conduct the member checking. Another area of concern that arose 
during the study was the need to be aware of and address any potential ADA 504 issues (e.g. hearing difficulties) students may have, and how that could affect the use of this technique in the classroom. Future studies may consider including multiple measures of graduate students' outcomes with a more diverse and larger sample size. Other basic counseling skills beyond active listening and reflective statements (e.g. summarizing, tracking, questioning, etc.) could be explored for a greater comprehension of the applicability of this creative training tool.

\section{Implications and Recommendations for Research}

The findings of this study have a number of implications for use in counselor education, particularly a skills training course. Results suggest that this technique could potentially be an effective and creative way to learn and practice reflective listening skills with counselors-intraining. This technique assists the counselor educator in moving away from more traditional and prescribed methods for teaching counseling skills for student mastery. Counselors-intraining who respond positively to experiential methods may find this method engaging, may participate more fully in class based activities, and seek additional creative methods for sharing and displaying their own knowledge. As a long-range implication, it is possible that by being instructed through experiential and creative methods in the classroom, counselors-in-training are being introduced to the idea of freedom to be creative in the techniques and approaches they use with clients in the field.

This technique has the potential to be utilized in other counseling coursework as a creative means for addressing specific topics. Future research could include expanding this concept to other areas of counselor pedagogy. For example, research could provide an in-depth look at how students understand and process the learning of diagnostic categories, multicultural issues, and theoretical conceptualization. The malleability of the technique lends itself to 
working with a number of other courses that frequently use case studies and role-plays as the primary methods for providing examples to students. The identification of diagnostic issues and symptomology displayed by clients, ethical issues, couple and family concerns, assisting students in identifying client concerns through the lens of a particular theoretical orientation, multicultural awareness and working with clients of diverse backgrounds, could all be viable coursework options in which this technique may prove effective.

\section{Conclusion}

Using music and lyrics as an experiential teaching tool represents a promising technique for assisting counselors-in-training in understanding at a deeper level the process of reflective listening. The technique was found to be effective, creative, adaptable, and engaging for students. This is a tool that raised counselor-in-training competence for understanding and working with reflective listening skills and can be used in additional courses to engage students with material. 


\section{References}

Anderson, T., Ogles, B. M., Patterson, C. L., Lambert, M. J., \& Vermeersch, D. A. (2009). Therapist effects: Facilitative interpersonal skills as a predictor of therapist success. Journal of Clinical Psychology, 65, 755-768. doi:10.1002/jclp.20583

Arronson, J. (1994). A pragmatic view of thematic analysis. The Qualitative Report, 2, 20-22.

Baker, F., \& Krout, R. E. (2011). Collaborative peer lyric writing during music therapy training: A tool for facilitating students' reflections about clinical practicum experiences. Nordic Journal of Music Therapy, 20(1), 62-89. doi:10.1080/08098131.2010.486132

Bogner, R. G., Horrocks, S. L., Lanni Manley, E. J., \& Denig, S. J. (2012). Educating counselors: A Constructivist approach to the development of core counseling skills. International Journal of Business and Social Science, 3, 1-8.

Boyatzis, R. E. (1998). Transforming qualitative information, thematic analysis, and code development. Thousand Oaks, CA: Sage.

Braun, V. \& Clark, V. (2006). Using thematic analysis in psychology. Qualitative Research in Psychology 3, 77-101. doi:10.1191/1478088706qp063oa

Buser, T. J. (2008). Counselor training: Empirical findings and current approaches. Counselor Education \& Supervision, 48(2), 86-100. doi: 10.1002/j.1556-6978.2008.tb00065.x

Carkhuff, R. R. (1969). Helping and human relations: A primer for lay and professional helpers. New York: Holt, Rinehart \& Winston.

Carkhuff, R. (2000). The art of helping (8th ed.). Amherst, MA: HRD Press.

Craig, D. (2009). Exploring music preference: Meaningfulness of music as a function of emotional reactions. Nordic Journal of Music Therapy, 18(1), 57-69. doi:10.1080/08098130802697137 
Crotty, M. (2003). The foundation of social research: Meaning and perspective in the research process. Thousand Oaks, CA: SAGE Publications.

Docherty, S., \& Sandelowski, M. (1999). Interviewing children. Research in Nursing and Health, $\quad 22, \quad 177-185 . \quad$ doi: $\quad 10.1002 / /($ SICI) 1098-240X(199904)22:2<177::AIDNUR9>3.0.CO;2-H

Foster, M. (2010). Pumped Up Kicks. On Foster the People [CD]. Los Angeles CA: Columbia Startime. (2009).

Furr, S. R., \& Carroll, J. J. (2003). Critical incidents in student counselor development. Journal of Counseling and Development, 81, 483-489. doi: 10.1002/j.1556-6678.2003.tb00275.x

Gladding, S., T. (2006). The counseling dictionary: Concise definitions of frequently used terms (2nd ed.). Upper Saddle River, NJ: Prentice-Hall.

Grbich, C. (2007). Qualitative data analysis: An introduction. Thousand Oaks, CA: Sage Publishing.

Grey, M., Ruzumna, J., Esses, B., \& Blue, J. (2000). Still [Recorded by Macy Grey]. On On How Life Is [CD]. New York, NY: Epic Records.

Harrawood, L. K., Mariska, M. A., \& Hill, N. R. (2013). Use of autobiographies to teach concepts in addiction: A narrative approach to instruction. Journal Of Creativity In Mental Health, 8(4), 470-482. doi:10.1080/15401383.2013.852445

Iarussi, M. H., Tyler, J. M., Littlebear, S., \& Hinkie, M. S. (2013). Integrating motivational interviewing into a basic counseling skills course to enhance counseling self-efficacy. The Professional Counselor, 3, 161-174. 
Ivey, A. E., Ivey, M. B., \& Zalaquett, C. P. (2010). Intentional interviewing and counseling: Facilitating client development in a multicultural society (7th ed.). Belmont, CA: Brooks/Cole.

Kerl, S. (2002). Using narrative approaches to teach multicultural counseling. Journal of Multicultural Counseling \& Development, 30(2), 135. doi: 10.1002/j.21611912.2002.tb00485.x

Koch, G., \& Dollarhide, C.T. (2000). Using a popular film in counselor education: Good Will Hunting as a teaching tool. Counselor Education and Supervision, 39, 203-210. doi:10.1002/j.1556-6978.2000.tb01232.x

LaRossa, R. (2005), Grounded theory methods and qualitative family research. Journal of Marriage and Family, 67, 837-857. doi: 10.1111/j.1741-3737.2005.00179.x

Lee, B., \& Prior, S. (2013). Developing therapeutic listening. British Journal of Guidance \& Counselling, 41(2), 91-104. doi:10.1080/03069885.2012.705816

Marmarosh, C. L., \& Kivlighan, D. M., Jr. (2012). Relationships among client and counselor agreement about the working alliance, session evaluations, and change in client symptoms using response surface analysis. Journal of Counseling Psychology, 59(3), 352-367. doi:http://dx.doi.org/10.1037/a0028907

McAnally, M. (1992). All These Years [Recorded by Sawyer Brown]. On Live and Learn [CD]. Nashville, TN: Curb Records.

McAuliffe, G. M. (2011). Deep learning. In G. M. McAuliffe \& K. Eriksen (Eds.). Handbook of counselor preparation: Constructivist, developmental, and experiential approaches. Thousand Oaks, CA: Sage. 
Nalavany, B. A., Ryan, S. D., Gomory, T., \& Lacasse, J. R. (2005). Mapping the characteristics of a 'good' play therapist. International Journal of Play Therapy, 14, $27-$ 50.doi:10.1037/h0088895

Nelson, M. L., \& Neufeldt, S. A. (1998). The pedagogy of counseling: A critical examination. Counselor Education and Supervision, 38, 70-89. doi:10.1002/j.15566978.1998.tb00560.x

Paladino, D. A., Barrio Minton, C. A., \& Kern, C. W. (2011). Interactive training model: Enhancing beginning counseling student development. Counselor Education and Supervision, 50(3), 189-206. doi:10.1002/j.1556-6978.2011.tb00119.x

Patten, M. L. (2007). Understanding research methods: An overview of the essentials (6th ed.). Glendale, CA: Pyrczak Publishing.

Pereira, J. K. \& Smith-Adcock, S. (2013). The effects of a training on school counselor trainee's attitudes, knowledge, and skills, and self-estimate of ability. International Journal of Play Therapy, 22(3), 129-142. doi: 10.1037/a0033388

Potrata, B. (2010). Rethinking the ethical boundaries of a grounded theory approach. Research Ethics, 6, 154-158. doi: 10.1177/174701611000600408

Ray, D. C., Jayne, K. M, \& Miller, R. M. (2014). Master counselors as teachers: Clinical practices of counselor educators. Journal of Mental Health Counseling, 36, 78-93.

Rogers Carl R. (1986). A client-centered/person-centered approach to therapy. Psychotherapist's Casebook: Theory and Technique in the Practice of Modern Times. Ed. I. L Kutash and A. Wolf. San Francisco: Jossey-Bass.

Shulman-Fagen, T. (2001). The creative arts in group supervision. In M. Forinash (Ed.), Music therapy supervision (pp. 149-160). Gilsum, NH: Barcelona. 
Smith, A. L. (2009). Role play in counselor education and supervision: Innovative ideas, gaps, and future directions. Journal Of Creativity In Mental Health, 4(2), 124-138. doi:10.1080/15401380902945194

Spruill, D. A., \& Benshoff, J. M. (2000). Helping beginning counselors develop a personal theory of counseling. Counselor Education and Supervision, 40, 70-80. doi:10.1002/j.1556-6978.2000.tb01800.x

Stinchfield, T. A. (2006). Using popular films to teach systems thinking. Family Journal, 14(2), 123-128. doi:10.1177/1066480705285559

Strauss, A., \& Corbin, J. (1998). Basics of qualitative research: Techniques and procedures for developing grounded theory (2nd ed.). Thousand Oaks: CA: Sage Publications.

Swank, J. M. (2012). Using games to creatively enhance the counselor education curriculum. Journal of Creativity in Mental Health, 7(4), 397-409. doi:10.1080/15401383.2012.740365

Tang, M., Addison, K. D., Lasure-Bryant, D., Norman, R., O’Connell, W., \& Stewart-Sicking, J. A. (2004). Factors that influence self-efficacy of counseling students: An exploratory study. Counselor Education and Supervision, 44, 70-80. doi:10.1002/j.15566978.2004.tb01861.x

Taub, D., \& Forney, D. (2004). Using entertainment media to inform student affairs teaching and practice related to counseling skills. New Directions for Student Services, 108, 7181. doi:10.1002/ss.143

Thompson, B. J., \& Hill, C. E. (1991). Therapist perceptions of client reactions. Journal of Counseling \& Development, 69(3), 261. 
Tudor, K., \& Merry, T. (2002). Dictionary of person-centered psychology. London, England: Whurr Publishers.

Villalba, J. A., \& Redmond, R. E. (2008). Crash: Using a popular film as an experiential learning activity in a multicultural counseling course. Counselor Education and Supervision, 47, 264-276. doi:10.1002/j.1556-6978.2008.tb00056.x

Ziff, K. K., \& Beamish, P. M. (2004). Teaching a course on the arts and counseling:

Experiential learning in counselor education. Counselor Education \& Supervision, 44(2), 147159. 


\section{APPENDIX A}

Client Case: As adapted from the song "Pumped Up Kicks", Foster the People (2010)

Robert is a 17 year old high school student. He comes to your office brought by his mother who states that Robert is "having great difficulty in school and with his friends but he won't let us do anything to help, he won't talk to me - he shuts me out"

In meeting with Robert you notice that he puts on a "cool" or "tough guy" act in your office. However, he appears to be a very quiet, introspective boy. Robert tells you there is no reason he needs to talk to you, that he "doesn't like school, it's for losers", and that he "doesn't care that he doesn't have very many friends" in school "the school is a joke anyway". He has two boys that he spends time with who also sound to be outside the "regular" group of $11^{\text {th }}$ graders. His mother reports that other than spending those two boys, Robert spends time alone in his room.

Robert is reluctant to talk about the bullying that his mother reports, saying "it's not a big deal - jocks are always jerks everyone knows that" while pounding on his chair. You can see that he is becoming agitated and he asks if he can smoke in your office. To your comment about his agitation Robert looks down and away and informs you with a shrug that the bullying isn't a big deal and he's "a lot tougher" than he looks. He states that people underestimate him, but "what goes around comes around eventually", again said with gestured emphasis. Following this statement Robert laughs to himself briefly. He then states that his friends get picked on too sometimes, but they're a group and they "look out for each other". Robert reinforces that he prefers to be alone.

Robert reports that his mom is a "worrier and a hoverer" and that she is "always on him about something”. Roberts father is rarely home due to the long hours he works and Robert 
reports that he is "a really tough guy - he's a man's man". Robert also states that he feels he is just like his father and particularly likes that his father "doesn't take any crap from anyone - this makes people respect him more". Robert's mother reports some relationship issues between herself and her husband, and states that Roberts father doesn't make much time for Robert. When asked about his relationship with his father Robert looks down and then out the window for several minutes. He then asks if his time is up. 